\title{
Evidence That the Nonstructural Protein of Tomato spotted wilt virus Is the Avirulence Determinant in the Interaction with Resistant Pepper Carrying the Tsw Gene
}

\author{
P. Margaria, M. Ciuffo, D. Pacifico, and M. Turina \\ Istituto di Virologia Vegetale, Sez. di Torino, CNR, Strada delle Cacce 73, Torino 10135, Italy
}

Submitted 29 August 2006. Accepted 11 December 2006.

\begin{abstract}
All known pepper cultivars resistant to Tomato spotted wilt virus (TSWV) possess a single dominant resistance gene, Tsw. Recently, naturally occurring resistance-breaking (RB) TSWV strains have been identified, causing major concerns. We used a collection of such strains to identify the specific genetic determinant that allows the virus to overcome the $T s w$ gene in Capsicum spp. A reverse genetic approach is still not feasible for TSWV; therefore, we analyzed reassortants between wild-type (WT) and RB strains. Our results confirmed that the S RNA, which encodes both the nucleocapsid protein $(\mathrm{N})$ and a nonstructural protein (NSs), carries the genetic determinant responsible for $T s w$ resistance breakdown. We then used full-length $S$ RNA segments or the proteins they encode to compare the sequences of WT and related RB strains, and obtained indirect evidence that the NSs protein is the avirulence factor in question. Transient expression of NSs protein from WT and RB strains showed that they both can equally suppress posttranscriptional gene silencing (PTGS). Moreover, biological characterization of two RB strains carrying deletions in the NSs protein showed that NSs is important in maintaining TSWV infection in newly emerging leaves over time, preventing recovery. Analysis of another RB strain phenotype allowed us to conclude that local necrotic response is not sufficient for resistance in Capsicum spp. carrying the $T s w$ gene.
\end{abstract}

Tomato spotted wilt virus (TSWV), genus Tospovirus, family Bunyaviridae, causes an important disease of pepper (Capsicum spp.) occurring worldwide (Adkins 2003), and the most effective and environmentally sound control strategy relies on the availability of resistant cultivars. Unfortunately all such cultivars possess the same single dominant resistance gene, called $T s w$ (Jahn et al. 2000). Plants carrying this gene usually show necrotic local lesions on the inoculated leaf, followed by premature abscission (Boiteaux 1995). The plant does not become systemically infected.

Boiteaux and Nagata (1993) first reported a TSWV resistance-breaking (RB) strain in Capsicum chinense. Several RB strains have now been reported from Italy in Capsicum spp. carrying the $T s w$ gene (Roggero et al. 1999, 2002) and, recently, new isolates have been reported in Spain (Margaria et al. 2004) and Australia (Thomas-Carrol et al. 2003).

Corresponding author: M. Turina; Fax: +39 011 343809; E-mail: m.turina@ivv.cnr.it
TSWV has a genome of three RNA segments: small (S) and medium (M) RNAs have ambisense coding strategies, whereas the large (L) RNA is of negative polarity. Jahn and associates (2000) have shown that the S RNA carries the genetic determinant for breakdown of $T s w$ resistance, but the specific avirulence factor has not been identified so far. The small segment is known to encode a nonstructural protein (NSs) in the positive strand and the nucleoprotein $(\mathrm{N})$ in the negative strand (de Haan et al. 1990).

A reverse genetic approach developed for viruses of the family Bunyaviridae has been described for the genera Nairovirus (Flick et al. 2003) and Bunyavirus (Bridgen and Elliot 1996) but, thus far, is not feasible for members of Tospovirus. However, reassortment experiments can generate progeny with different properties (Qiu et al. 1998) and, through this approach, plus sequencing of $M$ segments from thrips-transmissible and nontransmissible isolates, Sin and associates (2005) demonstrated the role of the M segment and in particular of the glycoprotein-carboxyl terminal (Gc) in transmissibility by thrips. Since the first reassortment study by Best during cross protection experiments between TSWV strains in 1961 (Best 1961), a few features have been unambiguously assigned to the different genome segments through this approach (Hoffmann et al. 2001; Jahn et al. 2000; Okuda et al. 2003). In this article, we show evidence that the NSs open reading frame (ORF) or its product is the source of $T s w$ resistance breakdown. We then discuss some of the molecular features associated with the TSWV-resistant pepper interaction that could be derived from a closer examination of some of the RB isolates from our collection.

\section{RESULTS}

Phenotype of RB strains.

Each strain used in our study (Table 1) was evaluated for its symptom phenotype on a set of host species generally used in TSWV studies, and the more relevant are reported in Table 2. All wild-type (WT) isolates produced the same classical symptoms (only necrotic lesion on inoculated leaves) on C. chinenseresistant accession number PI152225 (Fig. 1A and B). Symptoms of the various $\mathrm{RB}$ isolates varied somewhat. $\mathrm{RB}$ strains $\mathrm{p} 105^{\mathrm{RB}}, \mathrm{p} 105 / 1^{\mathrm{RB}}, \mathrm{p} 105 / 43.14^{\mathrm{RB}}, \mathrm{p} 105 / 44.7^{\mathrm{RB}}, \mathrm{p} 267^{\mathrm{RB}}, \mathrm{p} 272^{\mathrm{RB}}$, $\mathrm{Br} 20^{\mathrm{RB}}$, and $\mathrm{Ve} 427^{\mathrm{RB}}$ established systemic infections causing leaf chlorosis and yellow mottle, but no necrotic local lesion on the inoculated leaf (Fig. 1C and D). In contrast, infection by $\mathrm{RB}$ strain $\mathrm{p} 166^{\mathrm{RB}}$ produced a necrotic lesion on the inoculated leaf, like the wild type, followed by systemic necrotic lesions and leaf crumple but no yellowing (Fig. 1E and F). 
With the Sicilian isolates, we observed that $\mathrm{p} 202^{\mathrm{RB}}$ caused rapid lethal necrosis on Nicotiana benthamiana, whereas $\mathrm{p} 170^{\mathrm{WT}}$ and $\mathrm{p} 170^{\mathrm{RB}}$ gave a delayed and less aggressive response of leaf crumple and mild mosaic without necrosis. Interestingly, $\mathrm{p} 170^{\mathrm{RB}}$ and $\mathrm{p} 202^{\mathrm{RB}}$ did systemically infect resistant $C$. chinense, but the new leaves emerging after the onset of systemic infection had no symptoms and were not infected, as confirmed by Western blot analysis (data not shown), thus displaying a consistent recovery phenotype (Fig. $1 \mathrm{G}$ through I). Systemic infection followed by recovery also was observed for both $\mathrm{p} 170^{\mathrm{RB}}$ and $\mathrm{p} 202^{\mathrm{RB}}$ in C. annuum, Datura stramonium, and Solanum lycopersicum, whereas $\mathrm{p} 170^{\mathrm{WT}}$ severely infected all these hosts permanently without recovery. Isolates $\mathrm{p} 170^{\mathrm{RB}}$ and $\mathrm{p} 202^{\mathrm{RB}}$ caused systemic necrosis on $N$. tabacum, whereas $\mathrm{p} 170^{\mathrm{WT}}$ was limited to local infection. Moreover, isolates $\mathrm{p} 170^{\mathrm{RB}}$ and p202 ${ }^{\mathrm{RB}}$ were not able to infect Emilia sonchifolia and Ocimum basilicum, in contrast to the WT strain p170 $17 \mathrm{WT}$.

\section{Reassortant RB isolates.}

Inoculum ratios in favor of WT strain $\mathrm{Br} 01^{\mathrm{WT}}$ (10:1 and 5:1) helped to obtain reassorted progeny carrying two genome segments of the WT parental strain and only one of the RB strain. Among the various reassortants strains we concentrated on, three clones-IFA201 ${ }^{\mathrm{RB}}\left(\mathrm{Br} 01^{\mathrm{WT}}-\mathrm{p} 267^{\mathrm{RB}}\right), \mathrm{IFA} 231^{\mathrm{RB}}\left(\mathrm{Br} 01^{\mathrm{WT}}\right.$ $\left.\mathrm{p} 105 / 43.14^{\mathrm{RB}}\right)$, and IFA225 $5^{\mathrm{RB}}\left(\mathrm{Br} 01^{\mathrm{WT}}-\mathrm{Ve} 427^{\mathrm{RB}}\right)$ - had the $\mathrm{S}$ segment of the RB parental strain and the $\mathrm{M}$ and $\mathrm{L}$ segments of $\mathrm{BrO1}^{\mathrm{WT}}$ (Fig. 2; data not shown). Among the reassortants able to break resistance conferred by the $T s w$ gene, no WT $S$ segment was detected. Moreover, no reassortant carrying recombinant genomic RNAs was obtained in our study. The reassorted strains gave systemic infection in $C$. chinense PI152225, inducing symptoms similar to those of the RB parental strain.
Sequence analysis of $\mathrm{S}$ segments.

The length of the complete S RNA was 2,925 nucleotides (nt) for $\mathrm{p} 166^{\mathrm{RB}} ; 2,926 \mathrm{nt}$ for $\mathrm{p} 105 / 44.7^{\mathrm{RB}} ; 2,927 \mathrm{nt}$ for $\mathrm{p} 105^{\mathrm{WT}}$, $\mathrm{p} 105 / 43.14^{\mathrm{RB}}, \mathrm{p} 105 / 1^{\mathrm{RB}}, \mathrm{p} 105^{\mathrm{RB}}$, and $\mathrm{p} 267^{\mathrm{RB}} ; 2,934 \mathrm{nt}$ for $\mathrm{p} 272^{\mathrm{RB}}$, and $2,922 \mathrm{nt}$ for Ve $430^{\mathrm{WT}}$ and $\mathrm{Ve} 427^{\mathrm{RB}}$ compared with $2,916 \mathrm{nt}$ for Br01 ${ }^{\mathrm{WT}}$ (de Haan et al. 1990). Br20 ${ }^{\mathrm{WT}}$ and $\mathrm{Br} 20^{\mathrm{RB}}$ contained an S segment of 2,926 nt. The two Sicilian RB isolates had small deletions in the NSs region when compared with the WT Sicilian isolate p170 17 WT $(2,954 \mathrm{nt})$, giving $2,930 \mathrm{nt}$ for $\mathrm{p} 170^{\mathrm{RB}}$ and $2,961 \mathrm{nt}$ for $\mathrm{p} 202^{\mathrm{RB}}$ (which showed a slightly longer intergenic region).

Alignment of the S segment of RB isolates compared with the WT versions revealed multiple differences for each isolate in the coding and noncoding regions, but no single mutation was common to all the RB strains. However, most did not show any difference from the respective WTs in the $5^{\prime}$ and $3^{\prime}$ untranslated regions (UTR), leading to the conclusion that mutations in these regions are not involved in overcoming the $T s w$ resistance gene. Although the comparison among the various intergenic regions (IGs) showed a number of mutations, insertions, and deletions, confirming the hypervariable nature of this genomic region, strains $\mathrm{p} 105^{\mathrm{WT}}, \mathrm{p} 105 / 1^{\mathrm{RB}}$, and $\mathrm{p} 105^{\mathrm{RB}}$ had the exact same IG sequence. $\mathrm{Br} 20^{\mathrm{WT}}$ and $\mathrm{Br} 20^{\mathrm{RB}}$ also showed the same IG sequence. Taken together, these results imply that mutations in the intergenic region are not necessary to confer the RB phenotype in $T s w$ resistant pepper.

Analysis of the N and NSs proteins encoded by S RNA.

The size of the $\mathrm{N}$ protein was 258 amino acids (aa) for all the Italian and Spanish isolates, as described for $\mathrm{Br} 01^{\mathrm{WT}}$ (de Haan et al. 1990). The deduced amino acid sequence of the $\mathrm{N}$ protein was identical in all the Italian WT and RB strains. The

Table 1. Wild-type (WT) and resistance-breaking (RB) Tomato spotted wilt virus (TSWV) isolates used in this study

\begin{tabular}{|c|c|c|}
\hline TSWV isolate & Source $^{a}$ & Date of isolation \\
\hline $\mathrm{Br} 01^{\mathrm{WT}}$ & Brazil & 14 August 1996 \\
\hline $\mathrm{p} 105^{\mathrm{WT}}$ & Albenga (Italian Riviera)* & 7 August 1996 \\
\hline p166 $166^{\mathrm{RB}}$ & Albenga (Italian Riviera)* & 27 August 1998 \\
\hline $\mathrm{p} 267^{\mathrm{RB}}$ & Albenga (Italian Riviera)* & 28 May 2002 \\
\hline $\mathrm{p} 272^{\mathrm{RB}}$ & Albenga (Italian Riviera)* & 4 June 2002 \\
\hline $\mathrm{p} 105 / 1^{\mathrm{RB}}$ & IVV-Torino\# & 17 June 1999 \\
\hline $\mathrm{p} 105 / 44.7^{\mathrm{RB}}$ & IVV-Torino\# & 30 March 2000 \\
\hline p105/43.14 ${ }^{\mathrm{RB}}$ & IVV-Torino\# & $30 \operatorname{March} 2000$ \\
\hline $\mathrm{p} 105^{\mathrm{RB}}$ & IVV-Torino\# & 5 May 2006 \\
\hline $\mathrm{Ve} 430^{\mathrm{WT}}$ & Almeria (Spain)* & 2 October 2003 \\
\hline $\mathrm{Ve} 427^{\mathrm{RB}}$ & Almeria (Spain)* & 19 September 2003 \\
\hline $\mathrm{p} 170^{\mathrm{RB}}$ & IVV-Torino $^{\circ}$ & 20 September 2005 \\
\hline $\mathrm{p} 170^{\mathrm{WT}}$ & Sicily (Italy)* & 26 February 1999 \\
\hline $\mathrm{p} 202^{\mathrm{RB}}$ & Sicily (Italy)* & 5 August 1999 \\
\hline $\mathrm{Br} 20^{\mathrm{WT}}$ & Brazil & 10 January 2006 \\
\hline $\mathrm{Br} 20^{\mathrm{RB}}$ & IVV-Torino $^{+}$ & 10 March 2006 \\
\hline
\end{tabular}

$\mathrm{a} *=$ from the same field, $\#=$ experimentally derived from $\mathrm{p} 105^{\mathrm{WT}},{ }^{\circ}=$ experimentally derived from $\mathrm{p} 170^{\mathrm{WT}}$, and ${ }^{+}=$experimentally derived from $\mathrm{Br} 20^{\mathrm{WT}}$.

Table 2. Symptoms on noninoculated upper leaves of various plant species 2 weeks post inoculation with Tomato spotted wilt virus (TSWV) strains ${ }^{\mathrm{a}}$

\begin{tabular}{|c|c|c|c|c|c|c|c|c|c|c|c|}
\hline \multirow[b]{2}{*}{ Strain $^{c}$} & \multirow[b]{2}{*}{ N. benthamiana } & \multicolumn{2}{|c|}{ N. tabacum } & \multicolumn{2}{|c|}{ C. chinense $^{\mathrm{b}}$} & \multicolumn{2}{|c|}{ C. annuum } & \multirow[b]{2}{*}{ D. stramonium } & \multirow[b]{2}{*}{ S. lycopersicum } & \multirow[b]{2}{*}{ O. basilicum } & \multirow[b]{2}{*}{ E. sonchifolia } \\
\hline & & Loc & Syst & Loc & Syst & Loc & Syst & & & & \\
\hline$\overline{\mathrm{Br} 01^{\mathrm{WT}}}$ & $\ln$ & Nll & $\mathrm{nm}$ & nll & - & ym & ym & $\mathrm{m}$ & $\mathrm{nm}$ & ym & ym \\
\hline $\mathrm{p} 105^{\mathrm{WT}}$ & $\mathrm{m}, \mathrm{lc}$ & M & $\mathrm{m}$ & nll & - & ym & ym & $\mathrm{m}$ & $\mathrm{nm}$ & ym & $\mathrm{ym}$ \\
\hline $\mathrm{p} 170^{\mathrm{WT}}$ & $\mathrm{m}, \mathrm{lc}$ & Nll & - & nll & - & ym & ym & $\mathrm{m}$ & $\mathrm{nm}$ & ym & ym \\
\hline $\mathrm{p} 166^{\mathrm{RB}}$ & $\mathrm{m}, \mathrm{lc}$ & Nll & $\mathrm{nm}$ & nll & $\mathrm{nl}$ & ym & $\mathrm{ym}$ & $\mathrm{m}$ & $\mathrm{nm}$ & $\mathrm{ym}$ & $\mathrm{ym}$ \\
\hline $\mathrm{p} 267^{\mathrm{RB}}$ & $\mathrm{m}, \mathrm{lc}$ & Nll & $\mathrm{nm}$ & ym & ym & ym & ym & $\mathrm{m}$ & $\mathrm{nm}$ & ym & ym \\
\hline $\mathrm{p} 170^{\mathrm{RB}}$ & $\mathrm{m}, \mathrm{lc}$ & Nll & $\mathrm{nm}$ & $\mathrm{ym}$ & $\mathrm{rec}$ & $\mathrm{ym}$ & $\mathrm{rec}$ & $\mathrm{rec}$ & $\mathrm{rec}$ & - & - \\
\hline $\mathrm{p} 202^{\mathrm{RB}}$ & $\ln$ & Nll & $\mathrm{nm}$ & $\mathrm{ym}$ & rec & $\mathrm{ym}$ & rec & rec & rec & - & - \\
\hline
\end{tabular}

${ }^{a}$ When relevant, a distinction between local (Loc) and systemic (Syst) symptoms was recorded. Species from genera Nicotiana, Capsicum, Datura, Solanum, Ocimum, and Emilia . Legend: $\mathrm{ln}=$ lethal necrosis, lc $=$ leaf crumple, $\mathrm{nl}=$ necrotic lesions, $\mathrm{nll}=$ necrotic local lesion, $\mathrm{nm}=\mathrm{necrotic}$ mosaic, ym = yellow mosaic, $\mathrm{m}=$ mosaic, rec $=$ recovery, and $-=$ not infected as tested by Western blot analysis.

b $C$. chinense used for symptom evaluation was accession PI152225.

${ }^{\mathrm{c}} \mathrm{WT}=$ wild type and $\mathrm{RB}=$ resistance breaking 
Italian $\mathrm{N}$ protein coding sequences also were the same, except that $\mathrm{p} 267^{\mathrm{RB}}$ had $\mathrm{U}$ instead of $\mathrm{C}$ at nucleotide 266 , and both $\mathrm{p} 267^{\mathrm{RB}}$ and $\mathrm{p} 105 / 43.14^{\mathrm{RB}}$ had $\mathrm{A}$ instead of $\mathrm{U}$ in position 762 ; both are silent. Alignment of the $\mathrm{N}$ coding sequence of the Spanish WT and RB isolates showed A substituted for G (silent) at nucleotide 756.

The size of the NSs protein was predicted to be 467 aa for the northern Italian isolates compared with 464 aa for $\mathrm{Br} 01^{\text {WT }}$ (de Haan et al. 1990). The Sicilian isolate p170 wT also had a NSs protein of 467 aa (but differing in sequence from the northern Italian isolates), whereas p $202^{\mathrm{RB}}$ showed a doublebase deletion at position 1,171 , resulting in a predicted protein of 399 aa; moreover, p170 17 showed a deletion of $25 \mathrm{nt}$ at position 684, resulting in a predicted protein of 238 aa. For the two Spanish isolates, we predicted a NSs protein of 468 aa.

Alignment of the deduced amino acid sequences of the NSs ORFs of the RB strains showed one to two amino acid substitutions in the northern Italian, Spanish, and Brazilian strains compared with the NSs of the corresponding WT strain (Fig. $3 \mathrm{~A}, \mathrm{~B}$, and C). No single amino acid substitution was common

\section{Inoculated Noninoculated}

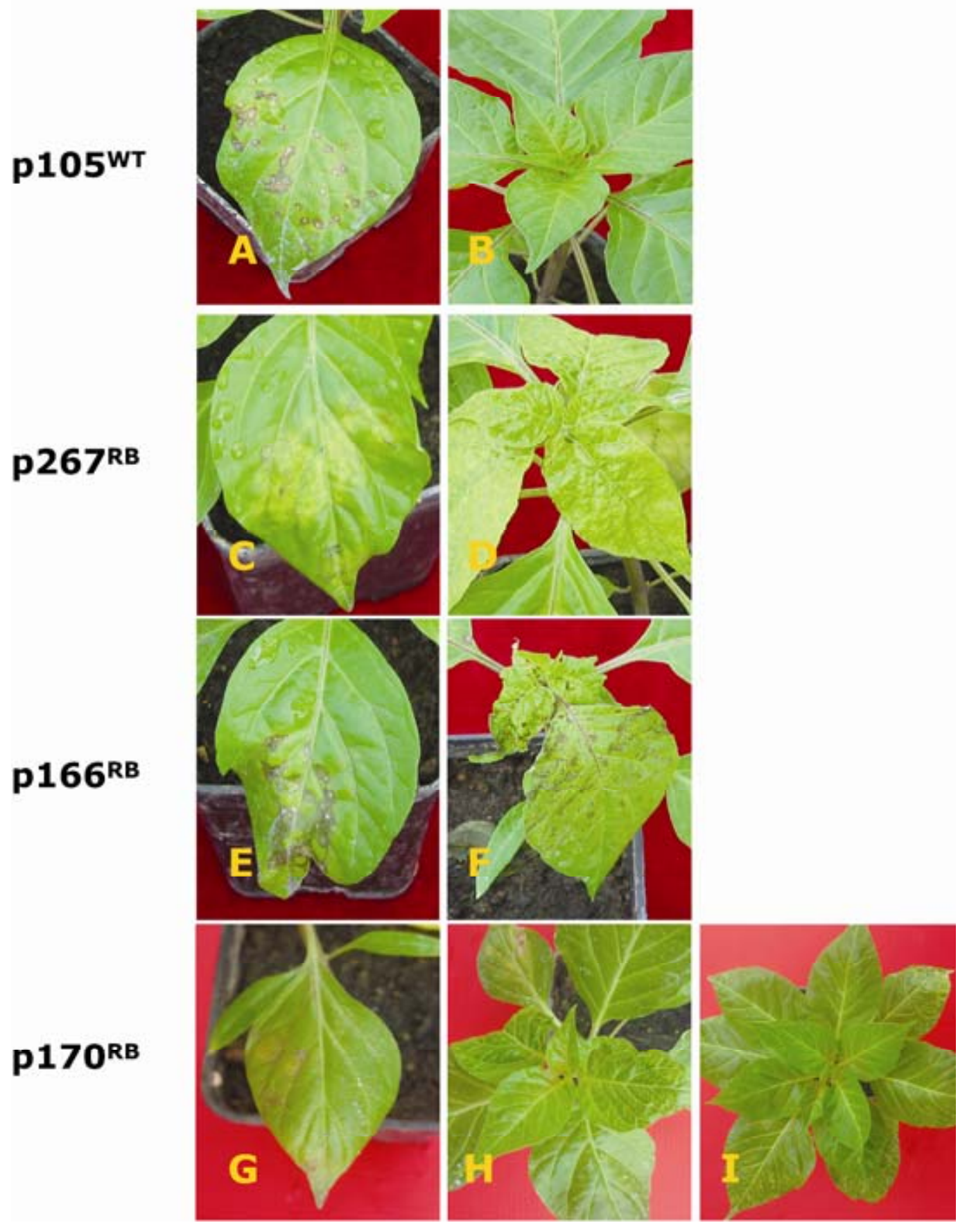

Fig. 1. Local and systemic symptoms of resistant pepper plants (Capsicum chinense PI152225) inoculated with some Tomato spotted wilt virus strains described in this study. A and B, Inoculated with the wild-type (WT) strain p105 ${ }^{\mathrm{WT}}$. C and $\mathbf{D}, \mathbf{E}$ and $\mathbf{F}$, and $\mathbf{G}$ and $\mathbf{H}$, were inoculated with the resistance-breaking (RB) strains p $267^{\mathrm{RB}}, \mathrm{p} 166^{\mathrm{RB}}$, and $\mathrm{p} 170^{\mathrm{RB}}$, respectively. A, C, E, and G, Plants evaluated 7 days post inoculation (dpi); B, D, F, and $\mathbf{H}$, evaluated 15 dpi. Different systemic symptom phenotype for strain $\mathrm{p} 166^{\mathrm{RB}}$ is to be noticed. I, Recovery of symptoms on newly emerged leaves at 30 dpi for $\mathrm{p} 170^{\mathrm{RB}}$-inoculated plants. 
to all the Italian RB strains. One substitution was common to $\mathrm{p} 267^{\mathrm{RB}}$ and $\mathrm{p} 105 / 43.14^{\mathrm{RB}}$ strains (I to $\mathrm{V}$ in position 437 ) and to $\mathrm{p} 272^{\mathrm{RB}}$ and $\mathrm{p} 105^{\mathrm{RB}}$ ( $\mathrm{Y}$ to $\mathrm{C}$ in position 78 ). The alignment of the NSs protein sequences of the Spanish isolates showed two

A

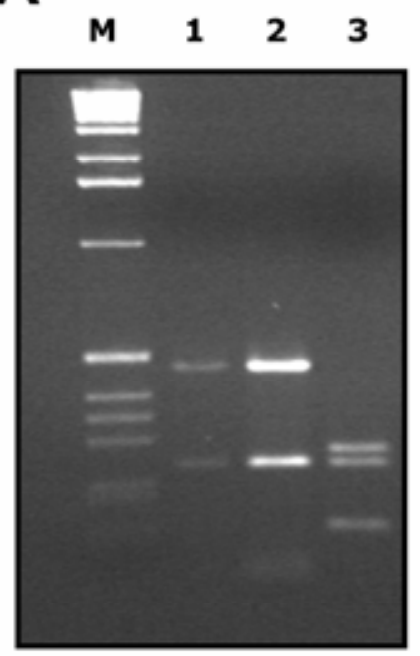

B

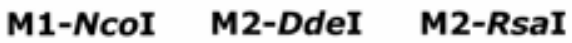

1

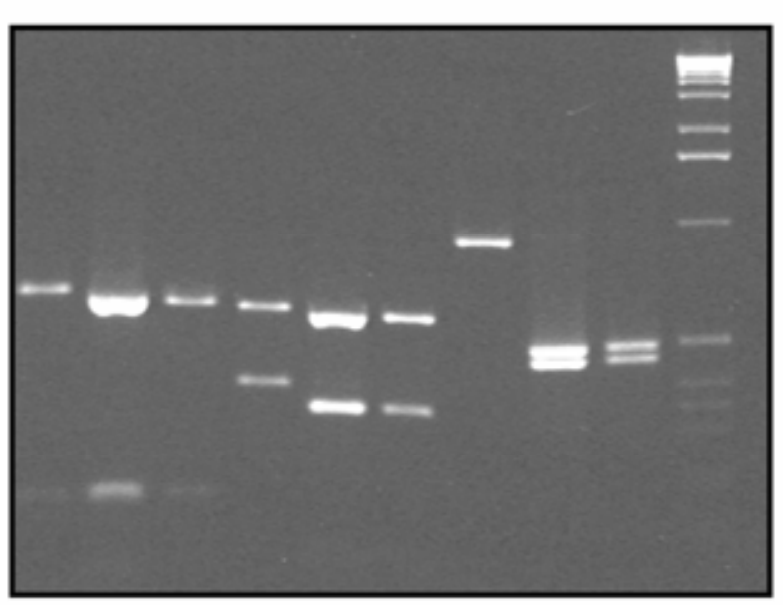

\section{L1-XbaI L2-HindIII L2-Bg/II}

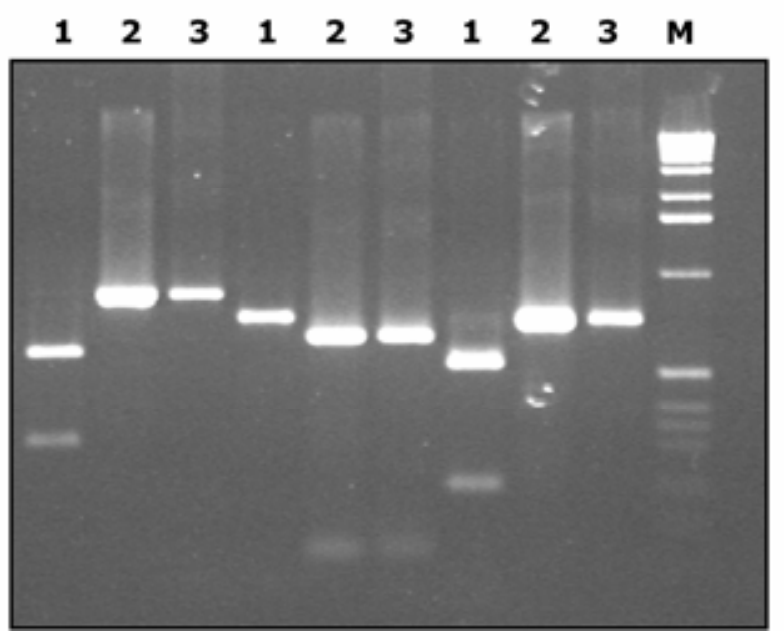

single substitutions at position 85 and 408 (Fig. 3B). A different substitution but in the same site was observed for $\mathrm{p} 267^{\mathrm{RB}}$ (Italian isolate) and Ve $427^{\mathrm{RB}}$ (Spanish isolate) (D to $\mathrm{V}$ and $\mathrm{D}$ to $\mathrm{N}$, respectively) in comparison with the related WT (Fig. 3A and $\mathrm{B}$ ). The Brazilian RB isolate had two amino acid changes compared with its WT at positions 174 and 255 (I to M and K to $\mathrm{N}$, respectively) (Fig. 3C). Alignment of the NSs proteins encoded by the Sicilian isolates is shown in Figure 3D. We looked at possible significant structural changes among the different NSs encoded by WT and RB strains with the protein prediction server (Rost 1996), but no obvious changes were noticed.

\section{Transient expression of S RNA-encoded proteins through viral vectors and agroinfiltration.}

A number of viral vectors for the expression of N and NSs proteins from WT and RB small genomic segments were derived from the Tomato bushy stunt virus (TBSV) vector TBSVgreen fluorescent protein (GFP)/p19 (Qiu et al. 2002) and from a Potato virus $X(\mathrm{PVX})$ expression vector, $\mathrm{pP} 2 \mathrm{C} 2 \mathrm{~S}$ (Chapman et al. 1992) (Table 3). In $N$. benthamiana and $N$. tabacum (not shown), the $\mathrm{N}$ protein (WT or RB allelic form) could be expressed abundantly by both TBSV (Fig. 4A) and PVX (not shown) vectors, whereas NSs protein expression never could be detected from either TBSV- (Fig. 4B) or PVX- (not shown) derived vectors. Northern blot analysis with RNA extracted from plants infected with TBSV-derived vectors (Fig. 4C) showed that full-length genomic segments containing the NSs coding region always failed to accumulate, whereas full-length genomic segments encoding for $\mathrm{N}$ or GFP could be detected. Most of the time, in the NSs-expressing vector, viral replication was shut down altogether; sometimes, a much-delayed accumulation of viral vector without insert could be observed. In both $C$. аппиит and C. chinense PI152225, $\mathrm{N}$ or NSs protein accumulation from both viral vectors could not be detected (not shown).

Fig. 2. Restriction fragment length polymorphism of the reverse-transcriptase polymerase chain reaction-amplified fragments of the large, medium, and small (L, M, and S, respectively) RNAs, used to determine the parental origin of the segments of one of the resistance-breaking (RB) reassortant isolates. A, S2 fragment digested by $T a q \mathrm{I}$ and S1 fragment digested with HindIII. B, Fragment M1 digested with $N c o$ I and fragment M2 digested with DdeI and RsaI. C, Fragment L1 digested with XbaI and fragment L2 digested with HindIII and BglII. In all panels, lanes 1, 2, and 3 correspond to digestion products from RB parental strain $\mathrm{p} 267^{\mathrm{RB}}$, reassortant strain IFA201 ${ }^{\mathrm{RB}}$, and wild-type (WT) strain $\mathrm{Br} 01^{\mathrm{WT}}$, respectively; $\mathrm{M}=$ 1-kbp DNA molecular weight marker (Gibco-Life Technology). Each panel shows that the reassortant isolate has the molecular markers of the $\mathrm{M}$ and L segment of the WT strain; whereas, for the S segment, the markers are those of the RB strain.

Table 3. List of recombinant viral vectors used in this study

\begin{tabular}{|c|c|c|}
\hline Name $^{a}$ & Vector $^{b}$ & Insert $^{\mathrm{c}}$ \\
\hline pTG-P19/wt & TBSV & GFP \\
\hline pTBSV - Br01 ${ }^{\mathrm{WT}} \mathrm{N} 3$ & TBSV & N WT \\
\hline pTBSV -p267 ${ }^{\mathrm{RB}} \mathrm{N} 7$ & TBSV & N RB \\
\hline pTBSV $-\mathrm{Br} 011^{\mathrm{WT}} \mathrm{NSs} 36$ & TBSV & NSs WT \\
\hline pTBSV -p267 RB NSs4 & TBSV & NSs RB \\
\hline $\mathrm{pP} 2 \mathrm{C} 2 \mathrm{~S}$ & PVX & - \\
\hline pP2C $2 \mathrm{~S}-\mathrm{Br} 01^{\mathrm{WT}} \mathrm{N} 14$ & PVX & N WT \\
\hline pP2C $2 S-272^{\mathrm{RB}} \mathrm{N} 8$ & PVX & N RB \\
\hline pP2C $2 \mathrm{~S}-\mathrm{Br} 01^{\mathrm{WT}} \mathrm{NSs} 10$ & PVX & NSs WT \\
\hline pP2C2S-272 ${ }^{\mathrm{RB}} \mathrm{NSs} 31$ & PVX & NSs RB \\
\hline
\end{tabular}

${ }^{\mathrm{a}} \mathrm{WT}=$ wild type and $\mathrm{RB}=$ resistance breaking.

b $\mathrm{TBSV}=$ Tomato bushy stunt virus and PVX = Potato virus $X$

${ }^{c} \mathrm{GFP}=$ green fluorescent protein, $\mathrm{N}=$ nucleocapsid protein, $\mathrm{NSs}=$ nonstructural protein, and $-=$ not infected. 
We then proceeded to evaluate the possibility to transiently express NSs (Fig. 4D) and N (not shown) proteins through agroinfiltration. Both proteins in both allelic versions (WT and $\mathrm{RB}$ ) accumulate abundantly in N. benthamiana and N. tabacum, confirming that NSs protein is not toxic in itself, but that its coding sequence likely interferes with virus vector replication. Agroinfiltration of pepper species with N- and NSs-expressing vectors failed to show any consistent accumulation of both proteins; in only a few instances, a limited accumulation could be observed (not shown). A necrotic response was caused by agroinfiltrating the empty vector (pBin61) masking possible elicitation of necrosis by some of the allelic forms of the two TSWV proteins (data not shown).

\section{Silencing suppression activity of NSs allelic forms from WT and RB strains.}

Given the possibility to express both full-length $\mathrm{NSs}^{\mathrm{WT}}$ and $\mathrm{NSs}^{\mathrm{RB}}$ through agroinfiltration, we first wished to check on the

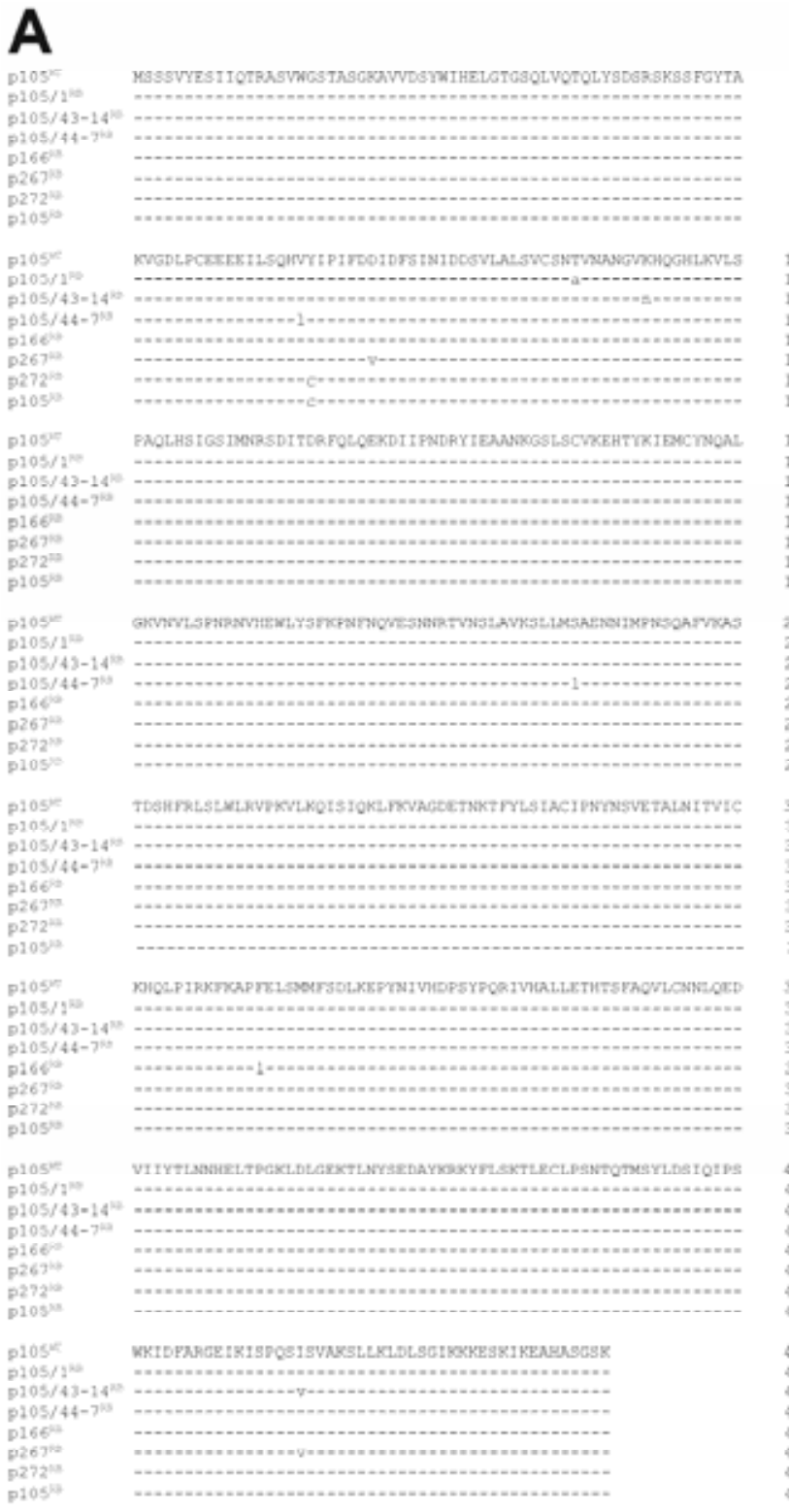

B

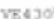

$\mathrm{VE} 430$
$\mathrm{~V} 423$

v:430"

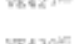

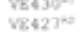

v8430"

VE42 $7^{\circ 5}$

VE430"
W.427

vะ430"t

VE427

$\mathrm{VE} 430 \mathrm{~m}$

$\mathrm{VE} 42310$

ve430"

VE427

C

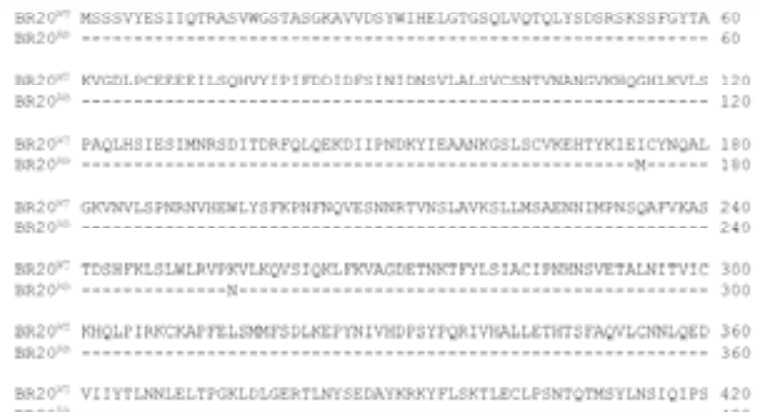

.

D

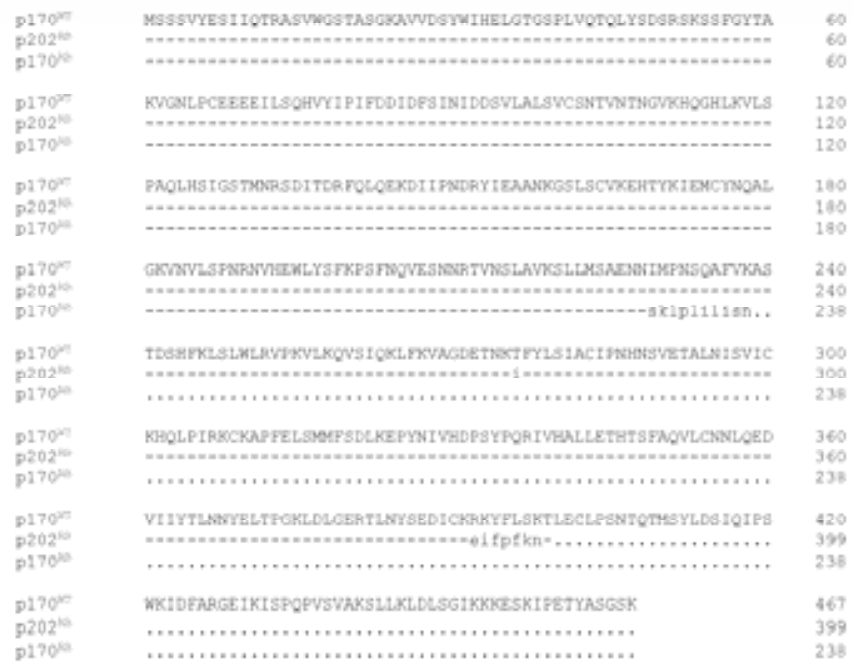

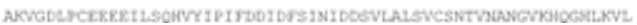

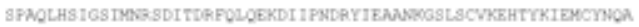

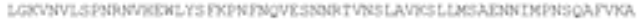

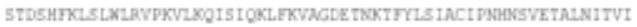

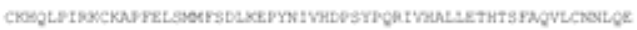
DWITYTLSYHELTSGLDUGERTIXYSEDAYKRKYFLSKTLECLPSWTOTKSYLS10TP

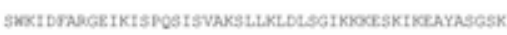

MSSSVYESI IOTRASWWGSTASGKOVVDSYWTHELOTGSPLVOTOLYSDQRSKSS FGYTA

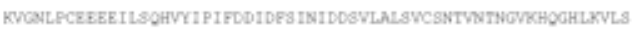

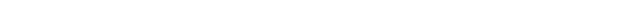

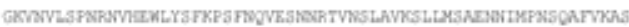

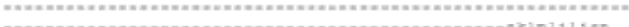

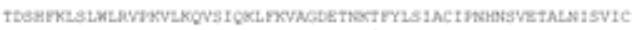

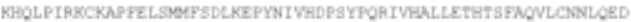

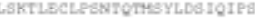
. WKIDEABGE 1KISPQPVSVhKSLLKLDLSGIKKLESKIFETYASGSK

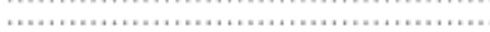

Fig. 3. Nonstructural protein amino acid sequence comparison among wild-type (WT) and resistance-braking (RB) Tomato spotted wilt virus strains. Identi$\mathrm{cal}$ amino acids are indicated by dashes; truncations by points. A, Compares p105 ${ }^{\mathrm{WT}}$ (the WT strain from the Italian Riviera) with closely related field or experimentally-derived RB strains. B, Compares a WT and an RB strain collected in the same field in Almeria (Spain). C, Compares a WT Brazilian isolate of our collection with an RB isolate directly derived from it by successive mechanical inoculations on $T s w$-resistant Capsicum annuum in our greenhouses. D, Compares isolate $\mathrm{p} 170^{\mathrm{WT}}$ (from Sicily) with a field isolate from Sicily $\left(\mathrm{p} 202^{\mathrm{RB}}\right)$ and an isolate derived from p170 ${ }^{\mathrm{WT}}$ in the greenhouse $\left(\mathrm{p} 170^{\mathrm{RB}}\right)$ through serial inoculation on C. chinense PI152225.

Vol. 20, No. 5, 2007 / 551 
ability of each of the two truncated NSs proteins to suppress silencing, a function previously shown to be performed by WT NSs (Bucher et al. 2003; Takeda et al. 2002). We checked GFP expression of agroinfiltrated $16 \mathrm{C} N$. benthamiana plants visually under a UV lamp and we were able to ascertain that both

A
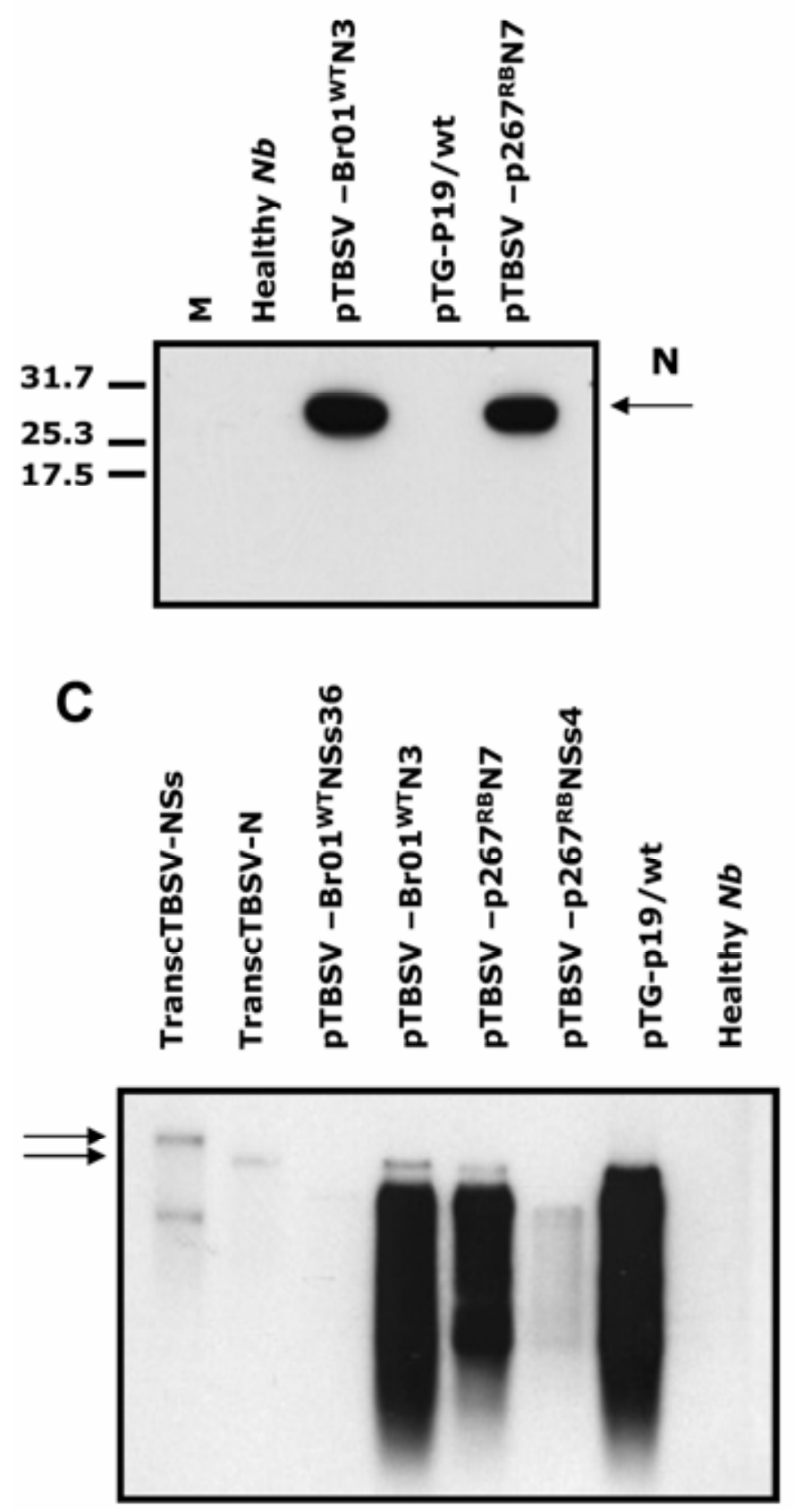

allelic versions from the WT and $\mathrm{RB}$ strains $\left(\mathrm{NSs}^{\mathrm{Br} 01}\right.$ and $\mathrm{NSs}^{\mathrm{p} 272}$ ) were able to equally suppress silencing when coinfiltrated with GFP (Fig. 5A). We then repeated the experiment, comparing a full-length NSs (from p272 ${ }^{\mathrm{RB}}$ ) with the truncated forms derived from Sicilian isolates. GFP expression was ob-

B
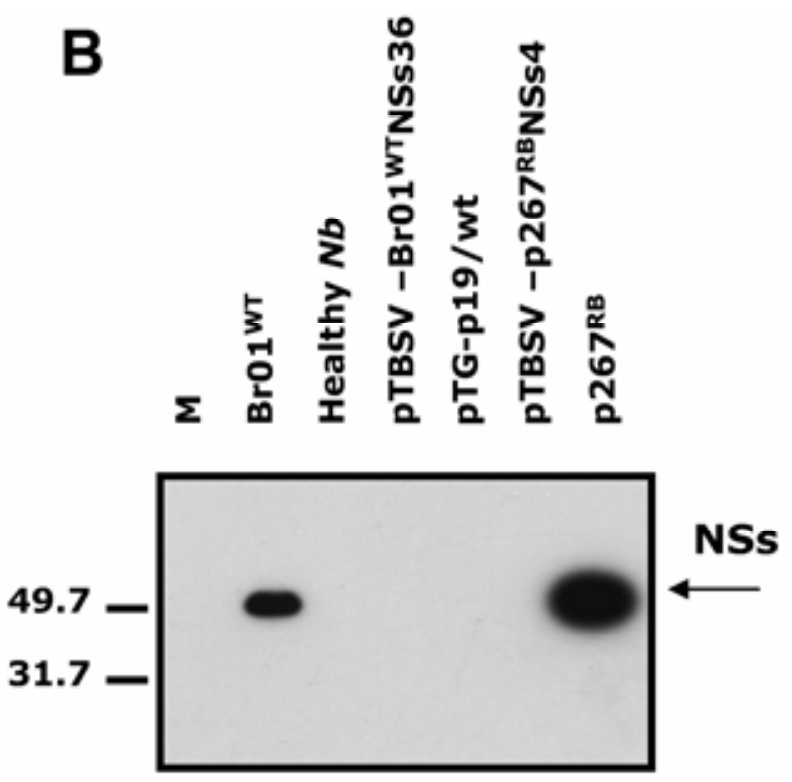

D

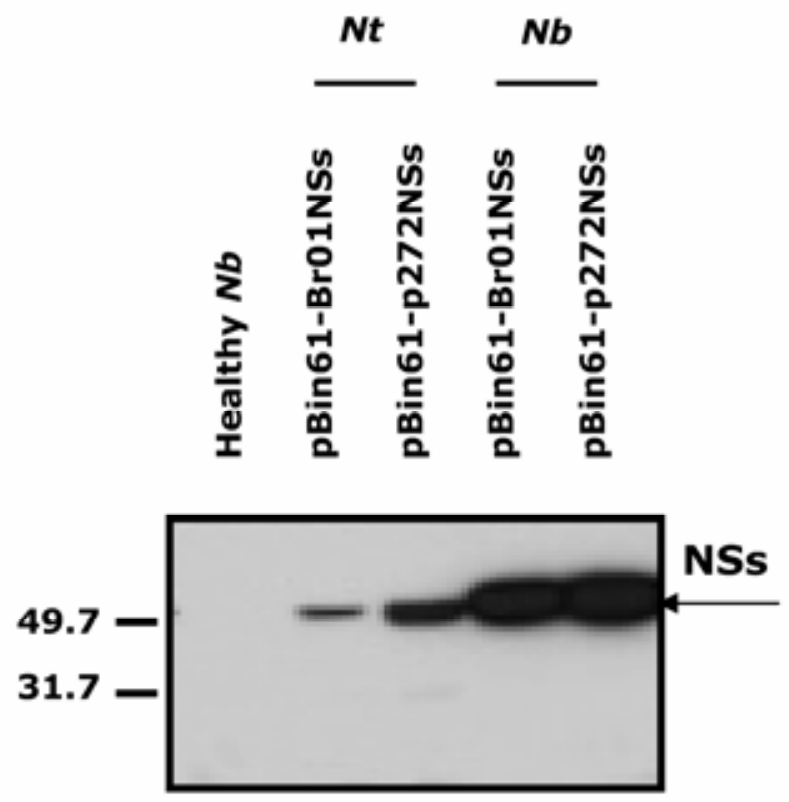

Fig. 4. Western and Northern blot analysis of total extracts from Nicotiana benthamiana ( $\mathrm{Nb}$ ) plants infected with transcripts derived in vitro from the Tomato bushy stunt virus (TBSV) vector clones or agroinfiltrated with pBin-derived clones. A, Primary antibodies were against Tomato spotted wilt virus (TSWV) nucleocapsid (N) protein. B, Primary antibodies were against nonstructural (NSs) protein. In both panels, each lane is labeled with the exact name of the viral vector from which transcripts were derived in vitro, and used to inoculate $N$. benthamiana plants (compare with Table 3 ). Lanes labeled with $\mathrm{Br} 01^{\mathrm{WT}}$ and $\mathrm{p} 267^{\mathrm{RB}}$ are loaded with plant extracts infected with the corresponding TSWV strains, and are used as positive control reference; $\mathrm{M}=$ protein molecular weight marker. The arrows point to the position of the $\mathrm{N}$ and NSs protein bands. C, Northern blot hybridization of RNA extracts from $N$. benthamiana plants after inoculation with TBSV vector recombinant transcripts. The membrane was probed with a mix of full-length TSWV S segment probe and a green fluorescent protein probe. Lanes are labeled with the TBSV constructs used to derive transcripts for mechanical inoculation (compare with Table 3); the two lanes labeled with "TranscTBSV-NSs" and "TranscTBSV-N" are loaded with $20 \mu 1$ of a 1/1,000 dilution of the transcript reaction from two of the clones representative of an N-and NSs-expressing vector. Arrows point to the position of the full-length transcript. The transcript reaction of the TBSV vectors expressing NSs always also contained a smaller band, possibly from an internal region recognized by the T7 RNA polymerase promoter. D, Western blot analysis for NSs protein expressed through agroinfiltration in $N$. benthamiana $(\mathrm{Nb})$ and $\mathrm{N}$. tabacum $(\mathrm{Nt})$. Lanes are labeled with the pBin61derived vectors. 
served with the full-length NSs from $\mathrm{p} 272^{\mathrm{RB}}$, indicating that silencing had been suppressed; however, the clones supposed to express the NSs-truncated forms from $\mathrm{p} 202^{\mathrm{RB}}$ and $\mathrm{p} 170^{\mathrm{RB}}$ did not suppress silencing (Fig. 5B). Given the lack of suppression of silencing from the truncated forms, we checked for their accumulation in agroinfiltrated leaves by Western blot analysis; neither of the NSs-truncated forms could be detected in Western blots, whereas accumulation of $\mathrm{NSs}^{\mathrm{p} 272}$ was abundant (data not shown). We then wanted to check whether the truncated proteins themselves were present at all in virus infected plants. Results for leaf extracts of D. stramonium in- fected with the WT $170^{\mathrm{WT}}$ and the two mutated RB strains $\mathrm{p} 170^{\mathrm{RB}}$ and $\mathrm{p} 202^{\mathrm{RB}}$ are shown in Figure 6A. A band of the expected size, of approximately $52 \mathrm{kDa}$, was observed for the control p170 ${ }^{\mathrm{WT}}$. A strong band of the expected size of 44.8 $\mathrm{kDa}$ also was present in extracts of plants infected with $\mathrm{p} 202^{\mathrm{RB}}$, but the $170^{\mathrm{RB}}$ expected band of $26.3 \mathrm{kDa}$ could not be observed, indicating possible instability or a limited capability to bind the primary NSs antibodies (a very faint band of similar size is present but also in the negative control). The expected $\mathrm{N}$ protein band was observed for all the three isolates (Fig. 6B).
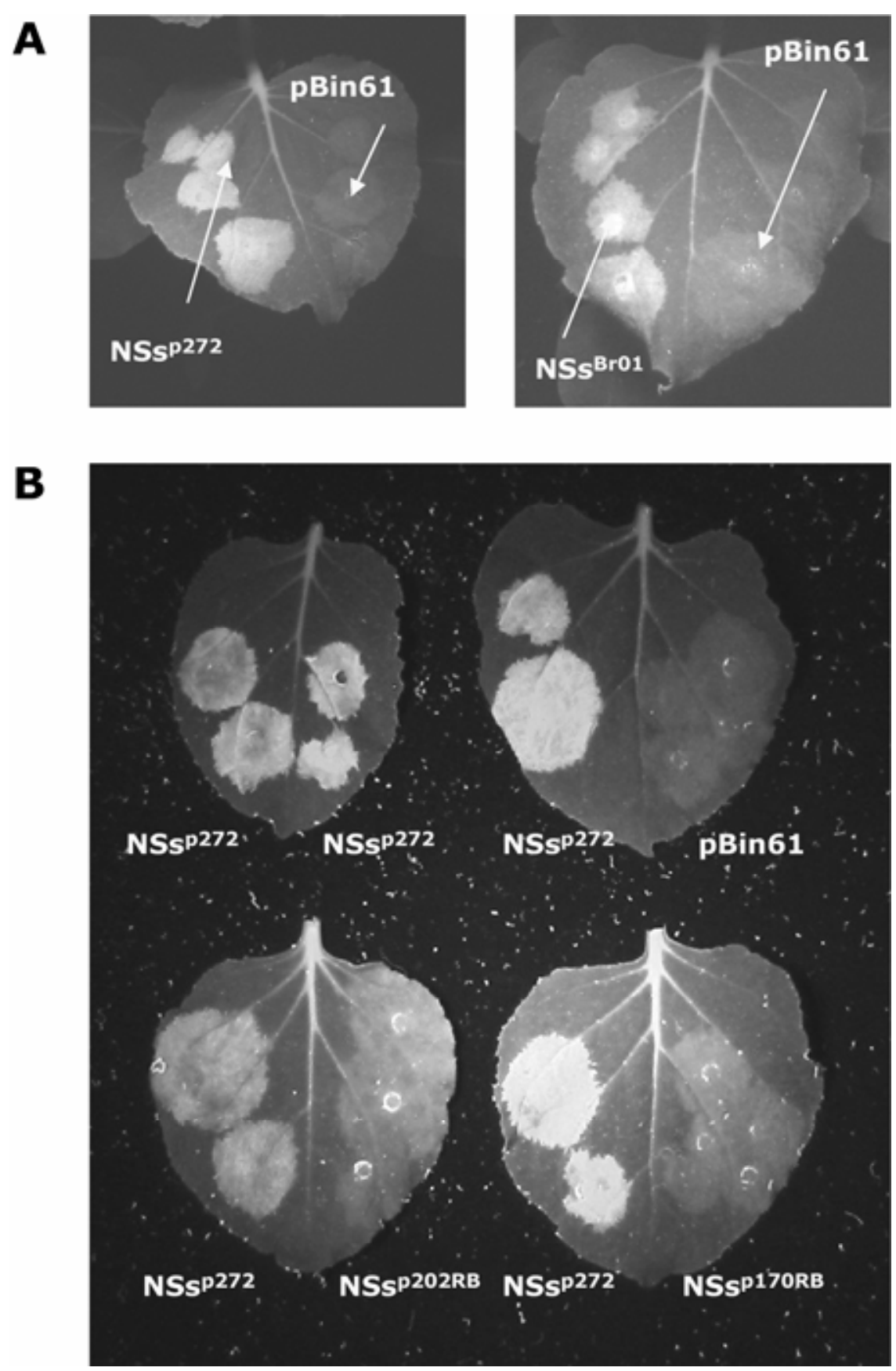

Fig. 5. Green fluorescent protein (GFP) expression on agroinfiltrated 16C Nicotiana benthamiana plants, photographed under UV light 7 days post agroinfiltration. Each construct was co-agroinfiltrated with a GFP-expressing plasmid. A, Nonstructural protein (NSs) alleles from wild-type (WT) (Br01 ${ }^{\mathrm{WT}}$ ), and resistance-breaking (RB) (p272 ${ }^{\mathrm{RB}}$ ) strains are equally capable of suppressing silencing; one-half of a leaf was inoculated with the empty vector itself (pBin61) and the other half with vectors expressing NSs from an RB $\left(\mathrm{NSs}^{\mathrm{p} 272}\right)$ or $\mathrm{WT}\left(\mathrm{NSs}^{\mathrm{Br} 01}\right)$ small Tomato spotted wilt virus segment cloned in $\mathrm{pBin61}$. B, Lack of silencing suppression from truncated NSs forms derived from Sicilian strains: one half of a leaf was inoculated with a known suppressor of gene silencing $\left(\mathrm{NSs}^{\mathrm{p} 272}\right)$ and the other half leaf was agroinfiltrated with pBin61 or with derived plasmids with the potential to express the truncated form of the NSs protein from $\mathrm{p} 202^{\mathrm{RB}}$ and $\mathrm{p} 170^{\mathrm{RB}}$ strains, respectively. 


\section{DISCUSSION}

Thus far, reassortment experiments have been the only tool available for TSWV, to link phenotypic features to molecular structures in individual genome segments (Hoffmann et al. 2001; Jahn et al. 2000; Qui and Moyer 1999; Qiu et al. 1998; Sin et al. 2005). In our work, reassortment experiments have shown that the S RNA is the carrier of the avirulence factor for the $T s w$ resistance gene, confirming a previous report of an $\mathrm{RB}$ strain (strain TSWV-A) from Hawaii (Jahn et al. 2000).

\section{dil 1/10}

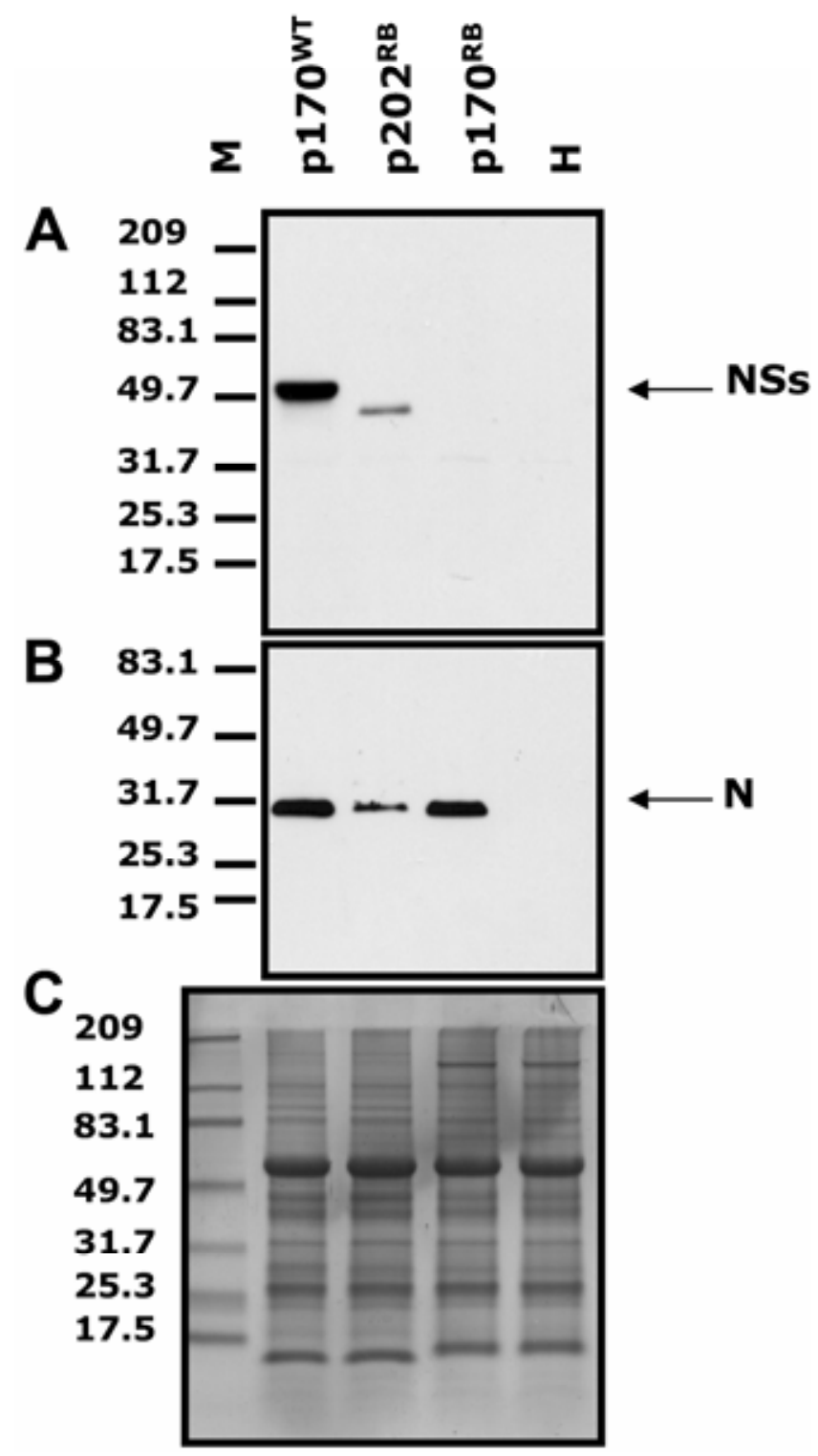

Fig. 6. Western blot analysis for nonstructural (NSs) and nucleocapsid (N) proteins from Datura stramonium plants inoculated with Sicilian wild-type (WT) and resistance-breaking (RB) Tomato spotted wilt virus (TSWV) isolates. A, Primary antibodies against protein NSs. B, Primary antibodies against $\mathrm{N}$ protein. Lanes are labeled with the name of the TSWV isolate; $\mathrm{H}=$ healthy $D$. stramonium extracts. Total protein extracts of systemically infected symptomatic leaves were prepared as described in Materials and Methods, except that $\mathrm{p} 170^{\mathrm{WT}}$ and $\mathrm{p} 202^{\mathrm{RB}}$ extracts were diluted $1 / 10$ in $D$. stramonium extract. C, Evaluation of total protein loadings through Coomassie staining of the gel. Arrows indicate the approximate position of NSs and $\mathrm{N}$ proteins; $\mathrm{M}=$ protein molecular weight marker.
Strain TSWV-A was able to overcome resistance in both pepper and tomato. In contrast, none of our pepper RB isolates could infect tomato plants carrying the $S w 5$ resistance gene (Roggero et al. 2002). However, it was not specified whether strain TSWV-A was isolated from a plant infected during an open field epidemic or upon a laboratory experiment. Furthermore, the whole $\mathrm{S}$ segment sequence was not published, likely because comparison with strain TSWV-D (used in the reassortment experiment) showed a number of differences in both ORFs, because the two strains are fairly distant phylogenetically (Tsompana et al. 2005). Thus, the significant mutations were not identified.

By contrast, in this study, we had the WT strains available from which the RB equivalents were derived, allowing us to closely compare related isolates. Thus, we can say that mutations in the $5^{\prime}$ and $3^{\prime}$ UTR, the N ORF, the $\mathrm{N}$ protein, and the intergenic region are not necessary for overcoming $T s w$ resistance, because a number of RB strain $\mathrm{S}$ segments have the same sequence as the related WT in these regions. In contrast, all the northern Italian, Spanish, and Brazilian RB strains contained one or two mutations in the NSs protein. Even deletions, resulting in truncated NSs proteins, were observed in NSs amino acid sequences from Sicilian RB isolates. Moreover, in three instances (amino acid positions 78, 84, and 437), the same amino acids were targeted by the selective pressure of the $T s w$ resistance gene in two distinct (and in one case phylogenetically distant) RB strains.

Several different mutations were distributed evenly through the RB NSs coding regions, and this may explain the relatively fast occurrence of $\mathrm{RB}$ strains in fields of resistant pepper hybrids. It also would suggest that the protein, when acting as an avirulence determinant, operates as a whole and not because of a single active domain. It seems unlikely that the multiple mutations we observed result from selective pressure of more than one resistance gene (or different alleles of $T s w$ ) present in the host plant population, because all the RB strains used in this study were isolated in open fields on resistant $C$. annuum hybrids or cultivars that are all well characterized and uniform for presence of a close molecular marker of the $T s w$ resistance gene. All the RB strains obtained under greenhouse conditions also were isolated on well-characterized $C$. annuum resistant cultivars (with the exception of $\mathrm{p} 170 \mathrm{RB}$, which was isolated from $C$. chinense PI52225). Generally, viral avirulence determinants are characterized through studies of chimeras between only two viral infectious clones (WT and RB). This approach is perfectly appropriate for the identification of a putative avirulence factor, but it may misrepresent and simplify the population aspects of avirulence determinants. Our study addresses this aspect by using several RB isolates. Tsompana and associates (2005) characterized a series of amino acid changes in the NSs of TSWV isolates collected from a variety of host plants and from different geographic locations. None of those represented an $\mathrm{RB}$ isolate. We did not observe any of those reported mutations in our collection of isolates, reinforcing the hypothesis that the amino acid changes we observed are, indeed, the result of $T s w$ gene selective pressure.

The function of the NSs protein is not completely understood. It can aggregate as fibrous structures in the plant cell cytoplasm (Kormelink et al. 1991), it is expressed in infectious thrips (Wijkamp et al. 1993), and it recently has been shown to be a suppressor of post-transcriptional gene silencing (PTGS) (Bucher et al. 2003; Takeda et al. 2002). Gene-silencing suppressors are often also proteins that interact with the host and determine viral host range; for instance, as shown for $\mathrm{p} 19$ of TBSV (Turina et al. 2003). Thus, our finding that NSs is the putative avirulence determinant is not unique. We then could 
demonstrate that lack of elicitation of resistance response from NSs of RB strains is not linked to loss of PTGS suppression capability (Fig. 5A), suggesting that NSs has at least two distinct functions, possibly with the involvement of distinct domains. Elicitation of resistance response and silencing suppression capability also were functionally and molecularly distinguished for TBSV p19 and Cucumber mosaic virus 2b proteins (Ji and Ding 2001; Lucy et al. 2000; Qiu et al. 2002; Turina et al. 2003). We then showed that a subset of RB strains did not express a full-length NSs protein (Fig. 6) and, indeed, one of the truncated form (NSs from p $202^{\mathrm{RB}}$ ) could be detected from virus-infected leaves.

Even though the role of NSs in suppressing PTGS was previously demonstrated using the Agrobacterium-mediated transient suppression assay (Bucher et al. 2003; Takeda et al. 2002), here we show for the first time the in planta role of NSs in maintaining the infection in newly emerging leaves, preventing recovery while not affecting initial long-distance movement. The functional link between recovery and silencing is one of the earliest findings with direct relevance to virus biology, which was obtained through research on PTGS (Covey et al. 1997; Ratcliff et al. 1997). To our knowledge, though, it is the first time that mutation in a suppressor of gene silencing is directly linked to a recovery phenotype, because most knock outs of silencing suppressors also affect other aspects of the viral infection cycle (such as severity of symptoms, long- or short-distance movement, or specific virus-host interactions) (Moissiard and Voinnet 2004). Agroinfiltration of clones putatively expressing truncated forms of NSs failed to show suppression of gene silencing, but no conclusion on their PTGS suppression capability can be drawn because NSs from $\mathrm{p} 202^{\mathrm{RB}}$ or $\mathrm{p} 170^{\mathrm{RB}}$ could not be detected in the preparations.

Virus-thrips molecular interaction currently is under close scrutiny (Whitfield et al. 2005), and particularly interesting is the finding that TSWV activates the thrips vector immune system (Madeiros et al. 2004). Given that NSs protein localizes abundantly in salivary gland tissues, and a hypothetical role in vector transmission has been suggested (Goldbach and Peters 1996), our NSs-defective strains provide us with the unprecedented opportunity to study the possible involvement of the NSs protein in the virus-thrips interaction. Reinforcing the hypothesis that the NSs is involved in virus-thrips interaction is the recent finding that TSWV NSs can suppress silencing in tick cells (Garcia et al. 2006).

It is interesting that the recovery phenotype is predicted to decrease virus fitness, because thrips selectively feed in the flower, which would be virus-free. In fact, the two Sicilian RB strains encoding a truncated NSs protein that result in recovery were not isolated during a field epidemic episode; $\mathrm{p} 202^{\mathrm{RB}}$ was found in an isolated susceptible field plant and $\mathrm{p} 170^{\mathrm{RB}}$ was isolated in the greenhouse following mechanical inoculation of resistant plants. On the contrary, all the isolates from field epidemics encoded for a full-length NSs protein, able to suppress gene silencing.

We have not excluded the possibility that the avirulence factor could be the RNA sequence of the NSs ORF. Studies on Cymbidium ringspot virus (Szittya and Burgyan 2001) and Melon necrotic spot virus (Diaz et al. 2004) point to involvement of a viral RNA sequence in host resistance breaking. However, it must be noted that, in all the RB strains, at least one amino acid mutation was present, suggesting a role of the protein itself.

The symptoms induced by $\mathrm{RB}$ strains on resistant $C$. chinense suggest that the TSWV-Tsw interaction involves cellto-cell movement, as suggested previously (Soler et al. 1999). In fact, even though most of the mutant RB strains did not cause necrotic local lesions on resistant $C$. chinense, the RB strain p166 retained this behavior and also caused necrotic lesions on the upper noninoculated leaves, indicating that local hypersensitivity at the start of infection is not a sufficient cause for resistance, as generally accepted and previously reported for this specific virus-host interaction (Moury et al. 1997). Precedents for separation between the hypersensitive responselike response and resistance response are present in the literature of the last decade (Bendahmane et al. 1999; Clough et al. 2000; Ehrenfeld et al. 2005); particularly relevant for plant viruses is the case study of Cauliflower mosaic virus infection of $N$. edwardsonii, where uncoupling of cell death from resistance also was demonstrated recently (Cawly et al. 2005)

Traditionally, a further confirmation that a certain protein is an avirulence determinant comes from studies of its transient expression through viral vectors or agroinfiltration (limiting the latter technique to elicitation of necrotic response, which, as discussed in the previous paragraph, is not always directly linked to resistance). In our case, efforts were inconclusive: on one side, viral vectors could not be used because NSs could not be expressed even in hosts where the viral vectors considered abundantly replicate and move; on the other side, agroinfiltration of the putative avirulence determinant on pepper failed to be consistent and gave an aspecific necrotic response (elicited by the empty vector itself) which masked a possible specific response.

\section{MATERIALS AND METHODS}

TSWV isolates and their maintenance.

The WT and related RB isolates we used are shown in Table 1. They consisted of five groups: from Brazil, the Italian Riviera, Sicily, Spain, and the Istituto di Virologia Vegetale (IVV) collection. The Brazilian isolate $\mathrm{Br} 01^{\mathrm{WT}}$ was used as type member of the genus and as the reference WT in the reassortment experiments. The first group included four field isolates $\left(\mathrm{p} 105^{\mathrm{WT}}, \mathrm{p} 166^{\mathrm{RB}}, \mathrm{p} 267^{\mathrm{RB}}\right.$, and $\left.\mathrm{p} 272^{\mathrm{RB}}\right)$ collected from commercial pepper cultivars carrying the $T s w$ gene grown in the same location in the Liguria region (northern Italy) (Roggero et al. 1999, 2002). The second group included four RB strains $\left(\mathrm{p} 105^{\mathrm{RB}}, \mathrm{p} 105 / 1^{\mathrm{RB}}, \mathrm{p} 105 / 44.7^{\mathrm{RB}}\right.$, and $\mathrm{p} 105 / 43.14^{\mathrm{RB}}$ ) isolated from the WT strain $\mathrm{p} 105^{\mathrm{WT}}$ at the IVV during the final evaluation steps of some breeding work carried out to introgress the $T s w$ gene in some local Capsicum cultivars under greenhouse conditions. Two Spanish field isolates (Ve430 ${ }^{\mathrm{WT}}$ and $\mathrm{Ve} 427^{\mathrm{RB}}$ ) collected in the same resistant $C$. annuum field in Almeria (Margaria et al. 2004) constituted the third group. Sicilian isolates constituted the fourth group: $\mathrm{p} 170^{\mathrm{WT}}$ and $\mathrm{p} 202^{\mathrm{RB}}$ were open-field isolates, whereas we derived the RB strain $\mathrm{p} 170^{\mathrm{RB}}$ from successive mechanical inoculations on resistant $C$. chinense during maintenance of $170^{\mathrm{WT}}$ in glasshouse condition. We recently obtained the last strain for our study $\left(\mathrm{Br} 20^{\mathrm{RB}}\right)$ by successive mechanical inoculations on $T s w$-resistant $C$. annuum of $\mathrm{Br} 20^{\mathrm{WT}}$, a strain present in our collection since 1995.

All isolates were passaged three times on $N$. tabacum through single lesions to avoid possible mixed infection and, subsequently, were multiplied systemically in $N$. benthamiana, E. sonchifolia, or both in a greenhouse at 22 to $25^{\circ} \mathrm{C}$. Tissue from these plants was frozen and stored in liquid nitrogen until further use. We determined the experimental host range for a number of the RB isolates on $C$. annuum, $N$. benthamiana, $N$. tabacum, $N$. glutinosa, Lycopersicon esculentum, O. basilicum, and E. sonchifolia as described by Roggero and associates (2002).

\section{Generation of reassortant isolates.}

Reassortant isolates were obtained by coinoculation of parental isolates onto $N$. benthamiana. $\mathrm{Br} 01^{\mathrm{WT}}$ was selected as 
Table 4. Restriction enzymes ${ }^{\mathrm{a}}$

\begin{tabular}{ll}
\hline Amplified fragment & Restriction enzyme \\
\hline S1 & HindIII, ClaI, EcoRI \\
S2 & TaqI \\
M1 & NcoI \\
M2 & DdeI, RsaI \\
L1 & $X b a \mathrm{I}, H p a \mathrm{I}$ \\
L2 $\left(\mathrm{p} 267^{\mathrm{RB}}\right)$ & HindIII, BglII \\
L2 $\left(\mathrm{Ve} 427^{\mathrm{RB}}\right)$ & ScaI \\
\hline a Enzymes used for restriction fragment length polymorphism analysis of \\
DNA fragments derived from reverse-transcriptase polymerase chain \\
reaction of large, medium, and small (L, M, and S, respectively) RNAs, \\
in order to determine the parental origin of the genomic segments of \\
resistance-breaking (RB) reassortant isolates.
\end{tabular}

Table 5. Primers used for small RNA reverse-transcriptase polymerase chain reaction amplification and sequencing

\begin{tabular}{ll}
\hline Primer & \multicolumn{1}{c}{$\mathbf{5}^{\prime}$ to $\mathbf{3}^{\prime}$ Sequence } \\
\hline p272-1F & agagcaattgggecataattttaattc \\
p105-1100F & tgatggttcatatccc \\
p105-1470R & catgcttcaggatcaa \\
Ve427-3000R & agagcaattgtgtcaatttattcaaa \\
p105-1F & agagcaattgtgtcataattt \\
Nc-2750R & ggctcgagacacatgtctaaggttaagctc \\
Nc2000-F & gggagctctttaagcaagttctg \\
\hline
\end{tabular}

the WT parent because it was biologically distinct from the other isolates and its genome sequence was sufficiently different from the RB strains to allow for restriction fragment length polymorphism (RFLP) analysis. Regarding the RB parents, p267 ${ }^{\mathrm{RB}}$ was chosen to represent the Italian RB strains collected in the field; $\mathrm{p} 105 / 43.14^{\mathrm{RB}}$ to represent the Italian RB strains obtained experimentally in glasshouse conditions, and $\mathrm{Ve} 427^{\mathrm{RB}}$ to embody the Spanish RB parental isolate. Three different ratios of inoculum $(1: 1,5: 1$, and $10: 1)$ of $\mathrm{Br} 01^{\mathrm{WT}}$ and the $\mathrm{RB}$ strain in question were mixed and coinoculated.

To select putative reassortants, systemically infected leaves of $N$. benthamiana from each of the different ratios and combinations of isolates were used to inoculate resistant $C$. chinense PI152225. We used systemically infected $C$. chinense tissue serially diluted to inoculate $N$. tabacum in order to obtain single local lesions. Ten single lesions were back-inoculated to $C$. chinense. Of those single lesion isolates able to systemically infect $C$. chinense, we determined the parental origin of the genome segments using the RFLP technique following the protocols described by Qiu and associates (1998). Representative reassortant strains also were passaged three times on $N$. tabacum to ensure clonality of each isolate.

\section{Molecular marker analysis.}

For each genome segment, two regions were amplified by reverse-transcriptase polymerase chain reaction (RT-PCR) as suggested by Qiu and associates (1998), using the oligonucleotides described in the same study, in order to obtain two markers for each genome segment, distant enough to check for internal recombination among homologous segments. In order to select restriction enzymes to be used for the RFLP analysis, we compared the complete genome sequence of $\mathrm{Br} 01^{\mathrm{WT}}$ (GenBank accession numbers NC_002050, NC_002051, and NC_002052) (de Haan et al. 1990, 1991; Kormelink et al. 1992 ) with that of $\mathrm{p} 267^{\mathrm{RB}}$, selected as representing the Italian isolates and $\mathrm{Ve} 427^{\mathrm{RB}}$, representing the Spanish isolates. Restriction enzymes for the Italian and Spanish isolates, which enabled us to analyze the reassortants, are shown in Table 4. Restriction fragments were visualized on a $1.2 \%$ agarose gel after staining with ethidium bromide.
Cloning and sequencing of the S RNA.

Total RNA was extracted from infected leaves of $N$. benthamiana as described previously (Turina et al. 1998), after three single-lesion passages on $N$. tabacum and a final inoculation on $T s w$-resistant $C$. annuum cv. Explorer. Two RT-PCR reactions for synthesis of first-strand cDNA were performed with the "Thermoscript RT-PCR System" (Invitrogen): one reaction employed random primers and the other used the specific reverse primer (Table 5) following the manufacturer's protocol. PCR amplifications were performed by placing $1 \mu \mathrm{l}$ of cDNA in $50 \mu \mathrm{l}$ of final reaction solution. Amplification consisted of one cycle at $94^{\circ} \mathrm{C}$ for $5 \mathrm{~min} ; 30$ cycles of $30 \mathrm{~s}$ of denaturation at $94^{\circ} \mathrm{C}, 30 \mathrm{~s}$ of annealing at $52^{\circ} \mathrm{C}$, and $90 \mathrm{~s}$ of extension at $72^{\circ} \mathrm{C}$; followed by one cycle of final extension for $10 \mathrm{~min}$ at $72^{\circ} \mathrm{C}$. As such, two overlapping products of 1.4 and $1.9 \mathrm{kbp}$ from each isolate were obtained to derive the entire $\mathrm{S}$ segment nucleotide sequence.

PCR-amplified viral cDNAs were cloned into pGem-T VECTOR (Promega) and competent Escherichia coli (D5 $\alpha$ strain) was transformed by standard molecular procedures. Recombinant clones were identified by blue-white screening and verified with PCR using the universal primers M13 f/r. Three separate cloning experiments for $\mathrm{p} 105^{\mathrm{WT}}$ and two for the others TSWV strains were performed in order to minimize potential sequence errors introduced by Taq polymerase. In the case of the RB strains, the consensus sequence was obtained from comparing the clones of each of their S segments with the corresponding WT strain, considering true only the conserved mutations in the RB sequences through the two cloning events. Each consensus sequence was deposited in GenBank (see accession numbers below).

Selected clones were sequenced from both ends with the universal primers M13 f/r and with internal specific deoxyoligonucleotides (TSWV-500-F: 5'-catgaacagatctgatat-3'; TSWV-2263R: 5'-tatatcaggatgcaaaat-3'). Sequence data were compiled using Chromas Lite (version 2.0; Technelysium). The BLAST program was used to compare related sequences available from GenBank database. Multiple alignments of the obtained sequences were done using ClustalW (Thompson et al. 1994).

\section{Recombinant TBSV and PVX vectors for the expression of $\mathrm{S}$ RNA-encoded proteins.}

TBSV- and PVX-derived clones are schematically represented in Table 3. TBSV clones were derived from digestion of clone pTG-p19/wt (Qiu et al. 2002) with XhoI and SacI restriction endonucleases to release the GFP insert to be replaced with PCR products corresponding to $\mathrm{N}$ and NSs coding region of the two allelic forms (WT and RB), using oligonucleotides described in Table 6. Each clone was sequenced along the whole insert. PVX vector-derived clones were obtained upon digesting the $\mathrm{pP} 2 \mathrm{C} 2 \mathrm{~S}$ vector (Chapman et al. 1992) with EcoRV and SalI and inserting the $\mathrm{N}$ and NSs coding region amplified by PCR with the oligonucleotides followed by restriction enzyme digestion, as indicated in Table 6. Transcripts were prepared and inoculated on plants as previously described (Turina et al. 1998).

\section{Agroinfiltration and Northern and Western blot analysis.}

Agrobacterium tumefaciens competent cells (strain C58C1) were transformed with recombinant plasmids derived from the expression vector pBin61 (Bendahmane et al. 2002; Hoefgen and Willmitzer 1988). First, the full-length S segments were obtained by RT-PCR using the oligonucleotide and reaction conditions previously described (Cortez et al. 2001), exploiting the BamHI site present in pBin61. These were used to obtain clones in both orientations for the $\mathrm{S}$ segment of the $\mathrm{Br} 01^{\mathrm{WT}}$ and $\mathrm{p} 272^{\mathrm{RB}}$ isolates. The obtained clones were named pBin61-Br01N, 
Table 6. Primers used for polymerase chain reaction amplification of DNA fragments to be cloned into the two viral vectors

\begin{tabular}{|c|c|c|c|}
\hline Fragment $^{\mathrm{a}}$ & Vector & Oligonucleotide name & $5^{\prime}$ to $3^{\prime}$ Sequence $^{b}$ \\
\hline $\mathrm{N}$ & TBSV & $\begin{array}{l}\text { TSWV-N2647-XhoI } \\
\text { TSWV-N2071-SacI }\end{array}$ & $\begin{array}{l}\text { ggctcgagacacatgtctaaggttaagctc } \\
\text { gggagctctttaagcaagttctg }\end{array}$ \\
\hline $\mathrm{N}$ & $\mathrm{pP} 2 \mathrm{C} 2 \mathrm{~S}$ & $\begin{array}{l}\text { TSWV-N2647-EcoRV-F } \\
\text { TSWV-N2071-SalI-R }\end{array}$ & $\begin{array}{l}\text { gggatatcatcatgtctaaggtta } \\
\text { agggtcgacttcaagcaagttctgcga }\end{array}$ \\
\hline NSs & TBSV & $\begin{array}{l}\text { TSWV-Ns-89-XhoI } \\
\text { TSWV-Ns-1492-SacI }\end{array}$ & $\begin{array}{l}\text { ggctcgagacacatgtcttcaagtgttt } \\
\text { gggagctcttattttgatcctgaagca }\end{array}$ \\
\hline NSs & $\mathrm{pP} 2 \mathrm{C} 2 \mathrm{~S}$ & $\begin{array}{l}\text { TSWV-Ns-89-EcoRV } \\
\text { TSWV-Ns-1492-SalI }\end{array}$ & $\begin{array}{l}\text { gggatatcttatttgatcctgaagca } \\
\text { gggtcgacacacatgtcttcaagtgttt }\end{array}$ \\
\hline
\end{tabular}

${ }^{a} \mathrm{~N}=$ nucleocapsid protein and NSs = nonstructural protein.

${ }^{\mathrm{b}}$ Restriction site sequences are indicated with bold type.

pBin61-p272N, pBin61-Br01NSs, and pBin61-p272NSs for the expression of $\mathrm{N}^{\mathrm{WT}}, \mathrm{N}^{\mathrm{RB}}, \mathrm{NSs}^{\mathrm{WT}}$, and $\mathrm{NSs}^{\mathrm{RB}}$, respectively.

To clone the NSs-coding region of strains $\mathrm{p} 272^{\mathrm{RB}}, \mathrm{p} 170^{\mathrm{RB}}$, and $\mathrm{p} 202^{\mathrm{RB}}$, respectively, the following primers were used that contain the BamHI restriction site (NSs89F: 5'-ggggatccacac atgtcttcaagtgttt-3'; NSs1492Rev: 5'-ggggatccttatttgatcctgaagca$\left.3^{\prime}\right)$. Each inserted fragment was sequenced. $N$. benthamiana plants were agroinfiltrated as previously reported (Bendahmane et al. 1999). Leaf extracts of virus infected or agroinfiltrated plants were prepared for protein separation and Western blot analysis as previously described (Turina et al. 1998) using 50 mg of tissue. Anti-NSs antibodies (Kormelink et al. 1991) and anti-N antibodies (Roggero et al. 2002) were used as primary antibodies at 1:1000 dilution. Bound antibodies were detected by anti-rabbit immunoglobulin $\mathrm{G}$ conjugated with horseradish peroxidase prepared in goat (Sigma), using the Supersignal West Pico Chemiluminescent Substrate (Pierce). Equivalent loading of total proteins in each sample was checked by Coomassie staining of gels in each experiment (Fig. 6C). Total nucleic acids from virus-infected plants were extracted, separated, and transferred to nylon membranes as previously detailed (Turina et al. 1998). Northern hybridization was carried out with digoxigenin-labeled DNA prepared as detailed in the protocols from the manufacturer (ROCHE Diagnostics) following hybridization and detection protocols detailed by the same manufacturer.

Experiments to evaluate silencing suppression capabilities were performed through coagroinfiltration of pBin-GFP and each of the NSs-expressing clones described previously on 16C transgenic $N$. benthamiana (Voinnet et al., 1998). For this purpose, a DNA fragment was amplified by PCR from the viral vector pTG-P19/wt using oligonucleotides GFP-EcoRV-F (5'aaagatatctccggccgatgagtaaaggag- $\left.3^{\prime}\right)$ and GFP-EcoRV-R (5'-gg gatatctatccggatttgtatagtt- $\left.3^{\prime}\right)$. The product was inserted into the SmaI site of pBin61 and sequenced with oligo pBinF (5'tgatgtgacatctccactg- $\left.3^{\prime}\right)$ to check for its right orientation. GFP expression was evaluated visually with a UV lamp (Blank Ray, Model B 100 AP).

\section{Nucleotide sequence accession numbers.}

Consensus sequences of the entire $\mathrm{S}$ segment of the different WT and RB strains were deposited in GenBank with the following accession numbers: DQ376177 to DQ376185 correspond to strain $\mathrm{p} 105 / 1^{\mathrm{RB}}, \mathrm{p} 105^{\mathrm{WT}}, \mathrm{p} 166^{\mathrm{RB}}, \mathrm{p} 267^{\mathrm{RB}}, \mathrm{p} 272^{\mathrm{RB}}$, $\mathrm{p} 105 / 43.14^{\mathrm{RB}}, \mathrm{p} 105 / 44.7^{\mathrm{RB}}$, Ve430 ${ }^{\mathrm{WT}}$, and $\mathrm{Ve} 427^{\mathrm{RB}}$, respectively; DQ398945 corresponds to strain p202 ${ }^{\mathrm{RB}}$; DQ431237 and DQ431238 correspond to strain $\mathrm{p} 170^{\mathrm{WT}}$ and $\mathrm{p} 170^{\mathrm{RB}}$, respectively; and DQ915946 to DQ915948 correspond to $\mathrm{p} 105^{\mathrm{RB}}, \mathrm{Br} 20^{\mathrm{RB}}$, and $\mathrm{Br} 20^{\mathrm{WT}}$, respectively.

\section{ACKNOWLEDGMENTS}

Grateful thanks to C. Perrone for technical assistance and to R. Milne for editing the manuscript. The vector TG-p19/wt was a gift from W. Qiu
(Southwest Missouri State University). $16 \mathrm{C} \mathrm{N}$. benthamiana plants and $\mathrm{PVX}$ vector $\mathrm{pP} 2 \mathrm{C} 2 \mathrm{~S}$ were obtained from D. Baulcombe at Sainsbury Laboratory, John Innes Center, Norwich, U.K.

\section{LITERATURE CITED}

Adkins, S. 2003. Tomato spotted wilt virus. Pages 39-40 in: Compendium of Pepper Diseases. K. Pernezny, P. D. Roberts, J. F. Murphy, and N. P. Goldberg, eds. American Phytopathological Society, St. Paul, MN, U.S.A.

Bendahmane, A., Kanyuka, K., and Baulcombe, D. C. 1999. The Rx gene from potato controls separate virus resistance and cell death responses. Plant Cell 11:781-791.

Bendahmane, A., Farnham, G., Moffett, P., and Baulcombe, D. C. 2002. Constitutive gain-of-function mutants in a nucleotide binding site-leucine rich repeat protein encoded at the Rx locus of potato. Plant $\mathrm{J}$. 32:195-204.

Best, R. J. 1961. Recombinant experiments with strains A and E of Tomato spotted wilt virus. Virology 15:327-339.

Boiteaux, L. S. 1995. Allelic relationships between genes for resistance to Tomato spotted wilt Tospovirus in Capsicum chinense. Theor. Appl. Genet. 90:146-149.

Boiteaux, L. S., and Nagata, T. 1993. Susceptibility of Capsicum chinense PI159236 to Tomato spotted wilt virus isolates in Brazil. Plant Dis. 77:219.

Bridgen, A., and Elliot, R. M. 1996. Rescue of a segmented negativestrand RNA virus entirely from cloned complementary DNAs. Proc. Natl. Acad. Sci. U.S.A. 93:15400-15404.

Bucher, E., Sijen, T., de Haan, P., Goldbach, R., and Prins, M. 2003. Negative-strand Tospoviruses carry a gene for gene silencing at analogous genomic positions. J. Virol. 77:1329-1336.

Cawly, J., Cole, A. B., Kiraly, L., Qiu, W. P., and Schoelz, J. E. 2005. The plant gene CCD1 selectively blocks cell death during the hypersensitive response to cauliflower mosaic virus infection. Mol. Plant-Microbe Interact. 18:212-219.

Chapman, S., Kavanagh, T. A., and Baulcombe, D. C. 1992 Potato virus X as a vector for gene expression in plants. Plant J. 2:549-557.

Clough, S. J. Fengler, K. A., Yu, I.-C., Lippok, B., Smith, R. K., and Bent, A. F. 2000. The Arabidopsis dnd1 "defense, no death" gene encodes a mutated cyclic nucleotide-gated ion channel. Proc. Natl. Acad. Sci U.S.A. 97:9323-9328.

Cortez, I., Saaijer, J., Wongjkaew, K. S., Pereire, A.-M., Goldbach, R., Peters, D., and Kormelink, R. 2001. Identification and characterization of a novel Tospovirus species using a new RT-PCR approach. Arch. Virol. 146:265-278.

Covey, S. N., Al-Kaff, N. S., Langara, A., and Turner, D. S. 1997. Plants combat infection by gene silencing. Nature 385:781-782.

de Haan, P., Wagemakers, L., Peters, D., and Goldbach, R. 1990. The S RNA segment of Tomato spotted wilt virus has an ambisense character. J. Gen. Virol. 71:1001-1007.

de Haan, P., Kormelink, R., de O. Resende, R., van Poelwijk, F., Peters, D., and Goldbach, R. 1991. Tomato spotted wilt virus L RNA encodes a putative RNA polymerase. J. Gen. Virol. 72:2207-2216.

Diaz, J. A., Nieto, C., Moriones, E., Truniger, V., and Aranda, M. A. 2004 Molecular characterization of a Melon necrotic spot virus strain that overcomes the resistance in melon and non-host plants. Mol. PlantMicrobe Interact. 17:668-675.

Ehrenfeld, N., Canon, P., Stange, C., Medina, C., and Arce-Johnson P. 2005. Tobamovirus coat protein $\mathrm{CPCg}$ induces an HR-like response in sensitive tobacco plants. Mol. Cell 19:418-427.

Flick, R., Flick, K., Feldmann, H., and Elgh, F. 2003. Reverse genetics for Crimean-Congo hemorragic fever virus. J. Virol. 77:5997-6006.

Garcia, S., Billecocq, A., Crance, J.-M., Prins, M., Garin, D., and Bouloy, M. 2006. Viral suppressors of RNA interference impair RNA silencing 
induced by a Semliki Forest virus replicon in tick cells. J. Gen. Virol. 87:1985-1989.

Goldbach, R., and Peters, D. 1996. Molecular and biological aspects of Tospoviruses. Pages 129-157 in: The Bunyaviridae. R. M. Elliot, ed. Plenum Press, New York.

Hoefgen, R., and Willmitzer, L. 1988. Storage of competent cells for Agrobacterium transformation. Nucleic Acids Res. 16:9877.

Hoffmann, K., Qiu, W. P., and Moyer, J. W. 2001 Overcoming host- and pathogen-mediated resistance in tomato and tobacco maps to the $\mathrm{M}$ RNA of Tomato spotted wilt virus. Mol. Plant-Microbe Interact. 14:242249.

Jahn, M., Paran, I., Hoffmann, K., Radwanski, E. R, Livingstone K. D., Grube, R. C., Aftergoot, E., Lapidot, M., and Moyer, J. 2000. Genetic mapping of the Tsw locus for resistance to the Tospovirus Tomato spotted wilt virus in Capsicum spp. and its relationship to the $S w-5$ gene for resistance to the same pathogen in tomato. Mol. Plant-Microbe Interact. 13:673-682.

Ji, L. H., and Ding, S. W. 2001. The suppressor of transgene RNA silencing encoded by Cucumber mosaic virus interferes with salicylic acid-mediated virus resistance. Mol. Plant-Microbe Interact. 14:715724

Kormelink, R., Elliot, W. K., de Haan, P., Zuidema, D., Peters, D., and Goldbach, R. 1991. The Nonstructural protein (NSs) encoded by the ambisense S RNA segment of tomato spotted wilt virus is associated with fibrous structures in infected plant cells. Virology 181:459-468.

Kormelink, R., de Hann, P., Meurs, C., Peters, D., and Goldbach, R. W. 1992. The nucleotide sequence of the M RNA segment of Tomato spotted wilt virus, a bunyavirus with two ambisense RNA segments. J. Gen. Virol. 73:2795-2840.

Lucy, A. P., Guo, H. S., Li, W. X., and Ding, S. W. 2000. Suppression of post-transcriptional gene silencing by a plant viral protein localized in the nucleus. EMBO (Eur. Mol. Biol. Organ.) J. 19:1672-1680.

Madeiros, R. B., Resende, R. D., and De Avila, A. C. 2004. The plant virus Tomato spotted wilt Tospovirus activates the immune system of its main insect vector, Frankliniella occidentalis. J. Virol. 78:4976-4982.

Margaria, P., Ciuffo, M., and Turina, M. 2004. Resistance breaking strains of Tomato spotted wilt virus (Tospovirus-Bunyaviridae) on resistant pepper cultivars in Almeria (Spain). Plant Pathol. 53:795.

Moissiard, G., and Voinnet, O. 2004. Viral suppression of RNA silencing in plants. Mol. Plant Pathol. 5:71-82.

Moury, B., Palloix, A., Gebre-Selassie, K., and Marchoux, G. 1997. Hypersensitive resistance to Tomato spotted wilt virus in three Capsicum chinense accessions is controlled by a single gene and is overcome by virulent strains. Euphytica 94:45-52.

Okuda, M., Taba, S., and Hanada K. 2003. The S RNA segment determines symptom differences on Tetragonia expansa between two Watermelon silver mottle virus isolates. Physiol. Mol. Plant Pathol. 62:327332.

Qiu, W. P., and Moyer, J. W. 1999. Tomato spotted wilt Tospovirus adapts to the TSWV gene-derived resistance by genome reassortment. Phytopathology 89:575-582.

Qiu, W. P., Geske, S. M., Hickey, C. M., and Moyer, J. W. 1998. Tomato spotted wilt Tospovirus genome reassortment and genome segment-specific adaptation. Virology 244:186-194.

Qiu, W.P., Park, J.-W., and Scholthof, H. B. 2002. Tombusvirus P19-medi- ated suppression of virus induced gene silencing is controlled by genetic and dosage features that influence pathogenicity. Mol. PlantMicrobe Interact. 15:269-280.

Ratcliff, F., Harrison, B. D., and Baulcombe, D. C. 1997. A similarity between viral defense and gene silencing in plants. Science 276:15581559.

Roggero, P., Melani, V., Ciuffo, M., Tavella, L., Tedeschi, R., and Stravato, V. M. 1999. Two field isolates of Tomato spotted wilt Tospovirus overcome the hypersensitive response of a pepper (Capsicum annuum) hybrid with resistance introgressed from $C$. chinense "PI152225". Plant Dis. 83:965.

Roggero, P., Masenga, V., and Tavella, L. 2002. Field isolates of Tomato spotted wilt virus overcoming resistance in pepper and their spread to other hosts in Italy. Plant Dis. 86:950-954.

Rost, B. 1996. PHD: Predicting one-dimensional protein structure by profile based neural networks. Methods Enzymol. 266:525-539.

Sin S.-H., McNulty, B. C., Kennedy, G. G., and Moyer, J. W. 2005. Viral genetic determinants for thrips transmission of Tomato spotted wilt virus. Proc. Natl. Acad. Sci. U.S.A. 102:5168-5173.

Soler, S., Diez, M. J., Rosellò, S., and Nuez, F. 1999. Movement and distribution of Tomato spotted wilt virus in resistant and susceptible accessions of Capsicum spp. Can. J. Plant Pathol. 21:317-325.

Szittya, G., and Burgyan, J. 2001. Cymbidium ringspot Tombusvirus coat protein coding sequence acts as an avirulent RNA. J. Virol. 75:24112420.

Takeda, A., Sugiyama, K., Nagano, H., Mori, M., Kaido, M., Mise, K., Tsuda, S., and Okuno, T. 2002. Identification of a novel RNA silencing suppressor, NSs protein of Tomato spotted wilt virus. FEBS (Fed. Eur Biochem. Soc.) Lett. 532:75-79.

Thomas-Carrol, M. L., and Jones, R. A. C. 2003. Selection, biological properties and fitness of resistance-breaking strains of Tomato spotted wilt virus in pepper. Ann. Appl. Biol. 142:235-243.

Thompson, J. D., Higgins, D. G., and Gibson, T. J. 1994. CLUSTAL W: Improving the sensitivity of progressive multiple sequence alignment through sequence weighting, positions-specific gap penalties and weight matrix choice. Nucleic Acids Res. 22:4673-4680.

Tsompana, M., Abad, J., Purugganan, M., and Moyer, J. W. 2005. The molecular population genetics of the Tomato spotted wilt virus (TSWV) genome. Mol. Ecol. 14:53-66.

Turina, M., Maruoke, M., Monis, J., Jackson, A. O., and Scholthof, K.-B. G. 1998. Nucleotide sequence and infectivity of a full-length cDNA clone of Panicum mosaic virus. Virology 241:141-155.

Turina, M., Omarov, R., Murphy, J. F., Bazaldua-Hernandez, C., Desvoyes, B., and Scholthof, H. B. 2003. A newly identified role for the Tomato bushy stunt virus P19 in short distance spread. Mol. Plant Pathol. 4:67-72.

Voinnet, O., Vain, P., Angell, S., and Baulcombe, D. C. 1998. Systemic spread of sequence-specific transgene RNA degradation in plants is initiated by localized introduction of ectopic promoterless DNA. Cell 95:177-187.

Whitfield A. E., Ullman, D. E., and German, T. L.. 2005. Tospovirus-thrips interactions. Annu. Rev. Phytopathol. 43:459-489.

Wijkamp, I., Van Lent, J., Kormelink, R., Goldbach, R., and Peters, D. 1993. Multiplication of Tomato spotted wilt virus in its vector Frankliniella occidentalis. J. Gen. Virol. 74:341-349. 